\title{
The Joint Declaration on the Doctrine of Justification and Social Ethics
}

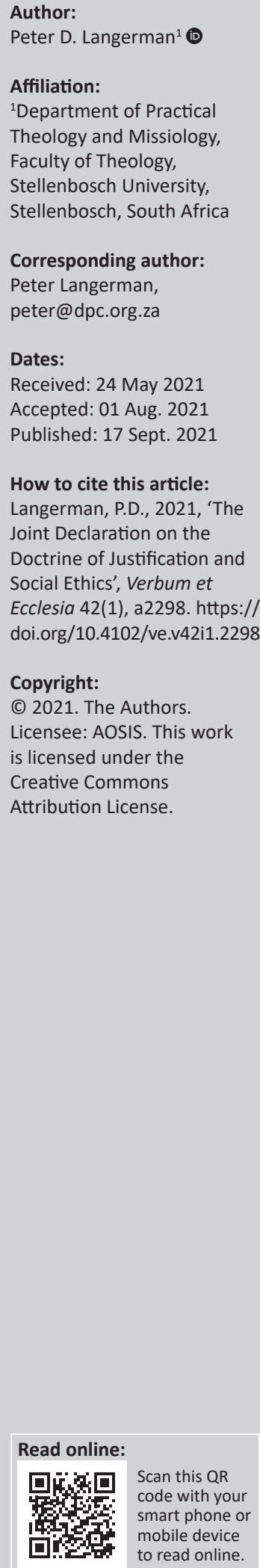

The Joint Declaration on the Doctrine of Justification (JDDJ) developed out of understanding of the doctrine of justification and how that doctrine relates to social ethics. The article briefly describes how the doctrine of justification and sanctification developed in various traditions and how it came to be seen in the liberal theological context of the late 19th century before a corrective in the middle of the 20th century. I examine the way in which the doctrine has been criticised by oppressed persons and how we might respond to those criticisms. Finally, a way forward is suggested that might help us to apply the significant gains of the JDDJ to the whole sphere of social ethics for us here in South Africa.

Intradisciplinary and/or interdisciplinary implications: This paper seeks to integrate the work done by the Joint Declaration on the Doctrine of Justification and Systematic Theology from an historical perspective via a literature survey so as to evaluate the JDDJ's impact on social ethics.

Keywords: JDDJ; justification; sanctifications; social ethics; doctrine.

\section{Introduction}

In the course of this article, I shall try to summarise some of the developments in the understanding of the doctrine of justification and how that doctrine relates to social ethics. I shall briefly describe how the doctrine of justification and sanctification developed in Roman Catholic, Reformed, Methodist and Pietist traditions, and how it came to seen in the liberal theological context of the late 19th century before a corrective in the middle of the 20th century. I shall examine the way in which the doctrine has been criticised by oppressed persons and how we might respond to those criticisms. Finally, I shall suggest a way forward that might help us to apply the significant gains of the Joint Declaration on the Doctrine of Justification (JDDJ) to the whole sphere of social ethics for us here in South Africa.

\section{The joint declaration}

On 31 October 1999, Reformation Day, representatives of the Roman Catholic Church and Lutheran World Federation signed a document which sought to codify the significant progress that had been made in discussions between these two organisations around the theological understanding of justification. Both sides also agreed to lift the various anathemas that had been issued from one side against the other since the Reformation.

Although the precise scope of the agreements reached in terms of the JDDJ go beyond the range of this article, it must be noted that, as Venema (2007:90) points out in his very comprehensive article, the Reformed and Lutheran Protestants and the Roman Catholics had to come to some sort of agreement on three distinct issues: the definition of justification itself; the basis of justification and the assurance of salvation.

These agreements, or progress towards them at least, are seen in the 'Common Understanding of the Doctrine of Justification' which is given in $\S \S 14-18$ of the JDDJ (2019:6ff.), and can be summarised as follows: 'Together we confess: By grace alone, in faith in Christ's saving work and not because of any merit on our part, we are accepted by God and receive the Holy Spirit, who renews our hearts while equipping and calling us to good works.' (§15). It affirms:

[J] ustification directs us in a special way towards the heart of the New Testament witness to God's saving action in Christ: it tells us that because we are sinners our new life is solely due to the forgiving and renewing mercy that God imparts as a gift and we receive in faith, and never can merit in any way. (§17) 
Further, it states:

Therefore the doctrine of justification, which takes up this message and explicates it, is more than just one part of Christian doctrine. It stands in an essential relation to all truths of faith, which are to be seen as internally related to each other. It is an indispensable criterion that constantly serves to orient all the teaching and practice of our churches to Christ. (§18)

This common understanding is then further explained and elaborated upon in seven sections, each one dealing with a different aspect of the common understanding of the doctrine of justification. Each section is divided into three parts: what is commonly understood; what Lutherans believe and what Catholics believe. It is not required that all should accept, merely tolerate, one another's positions. These sections are as follows:

$\S 4.1$. Human Powerlessness and Sin in Relation to Justification $\S 4$.2. Justification as Forgiveness of Sins and Making Righteous $\S 4.3$. Justification by Faith and through Grace

$\S 4.4$. The Justified as Sinner

$\S 4.5$. Law and Gospel

$\S 4.6$. Assurance of Salvation

$\S 4.7$. The Good Works of the Justified.

As ground-breaking and significant as the document is, the response to the Joint Declaration has not been universally positive. To simplify the objections to the JDDJ, some Roman Catholics felt that the document had made too many concessions to the Lutherans and some Lutherans felt that the document had made too many concessions to the Roman Catholics. In the meantime, despite their concerns around some of the theological formulations, the Anglican Consultative Council, the World Methodist Council and the World Communion of Reformed Churches have chosen to accept and sign the declaration as well. Therefore, while the content and wording of the document still remains slightly contested, the spirit behind it remains significant. It is this spirit which acknowledges the various aspects of the doctrine and theology of justification that the different faith traditions have in common.

In $\S 43$ of the JDDI, it states (italics added):

Our consensus in basic truths of the doctrine of justification must come to influence the life and teachings of our churches. Here it must prove itself. In this respect, there are still questions of varying importance which need further clarification. These include, among other topics, the relationship between the Word of God and church doctrine, as well as ecclesiology, ecclesial authority, church unity, ministry, the sacraments, and the relation between justification and social ethics. We are convinced that the consensus we have reached offers a solid basis for this clarification. The Lutheran churches and the Roman Catholic Church will continue to strive together to deepen this common understanding of justification and to make it bear fruit in the life and teaching of the churches.

It is the relation between justification and social ethics that I will consider in this paper.

\section{Social Ethics and its place in religious thought and experience}

In his book, Faith, Reason and Existence, John Hutchinson seeks, in his final chapter, to explain the links between religion, ethics and moral policies. Having discussed the concept of ethics and moral reasoning in some of the world's major religions, Hutcinson (1956) states:

[In Judaism and Christianity] the divine will, or purpose defines the meaning of human life, which is to do the will of God. And the content of this will is ethical action. (p. 276)

Having given a brief overview of the development of the concept of ethics as 'obedient love' (Hutcinson 1956:277), he then argues that: ' $[t]$ his conception of God as sovereign will, requiring of man a life of love, received its climatic expression in the teachings of Jesus Christ' (Hutcinson 1956:277). Hutcinson then talks about the relation between ethics and religion and the influence one has upon the other. He refers to Paul Tillich's concept of 'heteronomy, autonomy and theonomy' (Hutcinson 1956:280). When applied to ethics, theonomy is the:

[C]reatively and unfortunately rare state of affairs in which man is able, as it were, to look freely and spontaneously through himself to his divine source and goal. He is able to see the inalienable kinship of human self to God. His faith is a free commitment to the God who is no stranger but is perceived to be the origin and goal of the human self. (p. 280)

He then comments of the attempts by persons such as the Neibuhr's, Paul Ramsey, Anders Nygren, John Bennett and others to construct a theonomous ethic. Hutchinson contends that while' ... [a theonomous ethic $]$ rejects religious authoritarianism, it is clearly a theological ethic. The content of the ethic, as Ramsey contends, is obedient love' (Hutcinson 1956:281, italics added). Here we have a vitally important aspect of social ethics in a context of the Christian faith: it is an attempt to live out the Christian life as an expression of obedient love.

Hutcinson then points out that a theonomous ethic, thus understood, is primarily to be located theologically and not philosophically. 'In Pauline fashion it regards ethics not as the condition of faith, but as its spontaneous and unforced fruit' (Hutcinson 1956:281, italics added). This is a point well worth emphasising: a theonomous Christian ethic must flow from relationship with God, not as a re-requisite or pre-condition for such faith.

Hutcinson then distinguishes ethics understood in this sense from legalism and states the following, which is of central importance for our purpose here. In the following quote Hutcinson (1956) uses the word 'faith', it is clear that what he was saying refers more broadly to justification in general:

What sets men free from the treadmill of earning God's favor is that peculiar perception and appropriation of divine favor or grace which is known to religion as faith. Faith is opening oneself to God in such a way as to perceive the divine love for man. Thus one sees that the divine favor which man seeks in vain to earn is 
given free. The consequences of faith are forgiveness of past misdeeds and a new spirit of obedient love. This faith is the historical source out of which the ethic of human love or brotherhood has come. As Ramsey has put it, this faith in divine love is the crater out of which has burst forth the morality of love. (p. 282, [italics added])

If we understand the words 'faith in divine love' to broadly corelate with justification, we have a basis upon which to launch a discussion into the relationship between the consensus that has now been reached in the JDDJ and social ethics. A legitimate Christian social ethic is an expression of obedient love that flows from a relationship with God established through faith in God's love, or justification.

\section{The Ordo Salutis: Reformers and reformed theology}

Although we are looking at the nexus between social ethics and the doctrine of justification, the issue of social ethics is, in terms of the Reformed theology, in the arena of sanctification: the process of living out and giving external evidence of, and expression to, both individually and corporately, the reality of what happens internally when the persons are justified. However, this was a particular development within the Reformation because, as Louis Berkhof points out, amongst the early church fathers, there was very little distinction between the two concepts of justification and sanctification. It was Augustine who first introduced something of a difference between sanctification and justification, although he did not clearly distinguish between the two, but argued that sanctification was a part of justification. Augustine was a major influence on Thomas Aquinas who also did not make a clear distinction between justification and sanctification, but once again, stated that justification included sanctification. According to Aquinas, in justification, the person is infused with divine grace from Christ as a gift through participation in the sacraments. From God's perspective, this infusion of grace releases the person from the curse of original sin, imparts a permanent habit of inherent righteousness and creates the potential for further development, even perfection. Mortal sin can permanently destroy or neutralise this operation of divine grace, but venial sins and the sense of guilt that they bring can be overcome by the sacraments of penance and the eucharist. According to the Aquinas, from a human perspective, the good works that flow from faith infused with, and motivated by, love have merit before God and cause an increase in grace. Such works, however, would be impossible without the continuous work of grace in the human person. This whole process was known as justification, and it was this that was embodied in the Canons and decrees of the Council of Trent.

However, when the Council of Trent defined justification, it broke with late medieval scholasticism by asserting that no one is able to be justified on the basis of nature and the keeping of the law. In the Council's judgement, it is heretical to teach that human beings may obtain justification by means of their own merits alone. In order to remedy the consequences of sin and to redeem human beings, God sent his own Son to redeem those under the law and to secure their adoption as his children. This fairly moderate statement was tempered with three points of special importance. Firstly, according to the Council, justification is not a God-initiating event where Christ's righteousness is imputed to the believer by grace through faith, but a transformative process by which a sinner is made just. In this view then, justification is by faith only in the sense that it is faith which begins the process of justification, and it is grace that provides the resources to produce the works that enable the believer to progress in the process of justification. These meritorious good works enable the believer to eventually inherit eternal life. Secondly, and because of their insistence on the first point, the Council rejected any definition of justification premised on the basis of an imputed righteousness. The righteousness by which believers are justified is an infused or an inherent righteousness. It is both God's gift and the possession of the believer. Thirdly, and flowing from the first two points, the Council rejected any teaching that affirms a certainty of salvation for all who believe in Christ. They held that such teaching fails to take into account the remnants of sin in the believer with our remaining weakness, or the possibility of self-deception and vain confidence in the lives of those who may not be living in conformity with the law of God.

The Reformers, partly in order to distinguish their position from that of Aquinas and to make justification a separate article of doctrinal faith distinct from sanctification, introduced a definite ordo salutis:

[T] he process by which the work of salvation, wrought in Christ, is subjectively realised in the hearts and lives of sinners. It aims at describing in their logical order, and also in their interrelations, the various movements of the Holy Spirit in the application of the work of redemption. (Berkhof 1984:415-416)

For the Reformers, there was a clear distinction between justification and sanctification:

[Justification was] a legal act of divine grace affecting the judicial status of man, and [sanctification was] a moral or re-creative work changing the inner nature of man. But while they made a careful distinction between the two, they also stressed their inseparable connection. (Berkhof 1984:530)

According to Billings (2009):

Justification is irreducibly forensic, but it is accessed as part of the double grace of union with Christ - a "mystical union" of intimacy with the believer, of Christ dwelling within the believer. (p. 440)

Over against the Roman Catholic view, the Reformers did not consider sanctification as something imparted by ongoing participation in the sacraments, but as a supernatural and gracious work of the Holy Spirit primarily through the Word, but also, secondarily, through the sacraments (the visible Word) by which the Holy Spirit increasingly delivers the Christian from the debilitating forces of sin and death while empowering the Christian to live out the faith by means of good works. 
For the Reformers, the processes of justification and sanctification sought to deal with two distinct human problems caused by sin. Firstly, human beings are fallen creatures whose relationship with God has been broken and, secondly, as a result of that, human beings live in the midst of the consequences of their polluted sinful condition. Because human beings were unable to rescue themselves from either of these conditions, the Reformers recognised that God has to take the initiative in salvation by the Spirit primarily through Word and then also through the sacraments. In this regard, Venema (2007) states that:

Calvin's formulations are not merely polemical in the negative sense of repudiating features of the Roman Catholic view; Calvin's formulations are also polemical in the positive sense of aiming to provide a satisfactory answer to some typical Roman Catholic objections to the Protestant doctrine of justification. (p. 68)

The ordo salutis was developed as a way of understanding and explaining the process of salvation, the means by which God intervenes to rescue human beings from sin and then to alleviate human suffering. Therefore, the ordo salutis was developed to explain the means of dealing with these two problems. Justification was the means by which God intervened to restore the relationship between human beings and Godself and sanctification was the means by which human beings, by the power of the Spirit, were able to overcome and undo the consequences of their polluted sinful condition.

When it comes to Calvin, there is some disagreement about whether Calvin introduced an ordo salutis at all. Berkhof (1984:416) contends that: 'Calvin was the first to group the various parts of the order of salvation in a systematic way...' while recognising that this was a very preliminary attempt at such a process. Indeed, we might say that Calvin's ordo salutis was very simple, consisting of faith, justification and sanctification. Ronald (see Wallace 1959) writes:

Calvin defines what we receive from Jesus Christ by faith as a "double grace", or a twofold benefit, the whole of which can be summed up for the purpose of theological discussion under two headings: Justification and Sanctification. (p. 23)

Geoffrey Bromiley (1978) details the significant way in which Calvin dealt with the relationship between justification and sanctification:

Perhaps Calvin's most important contribution to the understanding of justification is his reuniting of two things which for purposes of clarity had in a sense been divided, namely, justification and sanctification. Now obviously neither Luther nor Cranmer nor others meant to keep the two apart. Their anxiety to relate faith to works bears ample testimony to this. On the other hand, the Reformers in general can hardly be said to have presented a comprehensive view of Christian salvation and the Christian life in a way which brings out the full relationship of justification and sanctification. This was to be the great achievement of Calvin. (p. 237)

Although Calvin regarded justification and sanctification as separate and distinct, he continually maintained that they were connected processes, as Billings (2009) argues:
Thus, not unlike the two natures of Christ as defined by Chalcedon, which are 'without confusion' or mixture, and yet 'without division' and 'without separation', Calvin argued for the inseparability (yet distinction) of the double grace based upon the oneness of Jesus Christ himself. (p. 435)

Garcia (2004) says of Calvin's understanding of the relationship between justification and sanctification that:

While bestowed concurrently, the twin benefits are logically ordered in such a way that sanctification is still, in an important respect, 'subordinate' to justification. In other words, the righteousness of the believer must not be confused with the righteousness of Christ. Only the latter is the meritorious ground of the believer's standing before God. The righteousness of works, however, in that they are in reality God's works in the believer, must not be opposed to the righteousness of Christ. The former is a subordinate, not a contrary, righteousness (p. 69)

Berkhouwer (1954), on the other hand, finds in Calvin not an ordo but an orderliness, which Calvin locates in salvation as the process of being incorporated into Christ:

Though one does not find an ordo salutis in Calvin, in the sense of its later development, there is nonetheless an order, perhaps better called an orderliness, which is determined by salvation in Christ. Salvation in Christ - this is the center from which the lines are drawn to every point of the way of salvation. The lines themselves may be called faith. (p. 29)

The difference between the interpretations of Calvin's position can be attributed to his overriding soteriological paradigm: that salvation consists of being 'in Christ' and all that flows as a consequence of that relationship. Much has been written about exactly what this phrase meant for Calvin and what influenced his use of the phrase ${ }^{1}$ and an analysis of this goes far beyond the scope of this article, and, as Billings (2009) states:

The phrase 'union with Christ' is best seen as shorthand for a broad range of themes and images which occur repeatedly through a wide range of doctrinal loci. These images are often clustered together - like participation in Christ, ingrafting in Christ, union with Christ, adoption and participation in God. Yet, the images function differently in different doctrinal and, at times, polemical contexts. (p. 419)

Nevertheless, Billings (2009) later summarises succinctly what he understands 'union with Christ' to mean:

By participation in Christ through faith, believers enter into a trinitarian drama of encountering a gracious Father who pardons our sin because of Christ's blamelessness (justification), and a powerful Spirit who sanctifies believers for new life (sanctification). Both of these aspects are accessed through participation in Christ - but both aspects would be dramatically altered if the two sides of the double grace were mixed or collapsed into one another. (p. 435)

Garcia (2009) explains that for Calvin:

[T] he distinctive righteousness of Christ, which is proper to him alone, is 'attributed' to believers only within and because of the 1.For a very thorough exploration of the historical background and major influences of Calvin see Garcia (2004). 
reality of their union with him. This 'attributed' righteousness, proper to Christ alone, is ours 'improperly' but truly because of the reality of the union ... Imputation is the attribution to the believer of the righteousness which is proper to Christ and yet truly the personal possession of the believer within the context of his union with Christ, the 'foundation' for this attribution. Put differently, in the indissoluble union of the believer with Christ, the righteousness which is proper only to Christ is attributed to the whole (Christ-and-the-believer-in-union) in such a way that the imputed righteousness truly belongs to the believer but, as far as justification is concerned, 'improperly', that is, by attribution. (p. 419)

In Methodism and Pietism, the emphasis was not on being in Christ, but on the importance of constant fellowship with Christ as a major component in sanctification. Where the Reformers tried to maintain the balance between justification and sanctification, the Methodists and Pietists tended to emphasise fellowship with Christ, with the result that they tended to favour sanctification over justification, with the attendant dangers of self-righteousness (Berkhof 1984):

Wesley did not merely distinguish justification and sanctification, but virtually separated them, and spoke of entire sanctification as a second gift of grace, following the first, of justification by faith after a shorter or longer period. While he spoke of sanctification as a process, he yet held that the believer should pray and look for full sanctification as a separate act of God. (p. 530)

In all three distinct views of sanctification, the role of good works is emphasised, for slightly different reasons. Good works in the sense of sanctification, whether seen as a result of participation in the sacraments or as a result of a supernatural work of the Spirit working through Word and sacrament or as a second gift of the Spirit, are an integral part of the process. Such works, regarded in a theological sense, are works of which God not only approved, but works that are regarded as rewards. They flow from the heart that has received the grace and mercy of God because no person has the disposition to obey God and the motive to glorify God without the power of the Spirit. They are not only acts, but also acts by which the human being consciously obeys the will of God because the person loves God and desires to please God. They are acts which may have as their result human welfare, but their actual aim is to glorify and honour God.

\section{Karl Barth: Union with Christ}

The Roman Catholic understanding of sanctification via good works inspired and motivated by participation in the sacraments, the Reformed adaptations to the ordo salutis and the Methodist and Pietist contention that perfect sanctification is possible in this life were all profoundly affected by Rationalism and the moralism of Kant. Under this influence, sanctification took on the flavour of a natural progression of the moral improvement of human beings rather than as a supernatural work of the Holy Spirit. For Schleiermacher, sanctification was regarded as the deepening of the God-consciousness within the human being taking over from the morally defective world-consciousness that was appreciated via the senses alone. Ritschl interpreted sanctification as moral perfection into which we develop through following our calling as members subject to the rule and reign of God. For the liberal theologians, sanctification meant nothing more than the gradual transformation of human beings' lower nature by the domination of the higher self - a sort of moral evolution of the human being to higher states of being. Under the influence of Liberalism, by the middle of the 20th century sanctification had come to mean acting morally and had been effectively replaced by the notion of the character development.

Karl Barth and the rise of the neo-orthodox movement changed that substantially. In his famous lecture before the Aarau Stadtkirche on 16 January 1916 on the 'righteousness of God', Barth gave an indication of the direction in which his theology would develop one day. Because human beings were unable to deal with the true righteousness of God, human beings substitute the righteousness of God with three specific substitutes. Firstly, moral righteousness, which locates within the confines of the family or tribe, or the state. Secondly, legal righteousness, which directs human righteousness towards endorsing the ends specified by the state, to achieving the ends set by the state itself. And thirdly, religious righteousness, which is an idol created by human beings to avoid the dictates of human conscience, which has its goal the ends set by the religious establishment.

The First World War, as far as Barth was concerned, exposed the failure of human conceptions of righteousness and led to a re-evaluation of the righteousness to God. These false conceptions of righteousness that humans had invented to avoid dealing with the righteousness of God were a false god and were the most prominent but least recognised casualty of the war (McGrath 2000):

The death of this God has forced man to recognize that the 'righteousness of God' is qualitatively different from, and stands over against, human conceptions of righteousness. (p. 359)

Although this is very early in Barth's theological journey it demonstrates the early signs of his Christological approach to theology, in terms of which he regards soteriology almost exclusively from the perspective of Christ, rather than from the individual human perspective. Barth rejects the ordo salutis as a series of distinct but interconnected events like links of a chain, but emphasises, much as Calvin did, that the blessings of justification, adoption, sanctification and all the others come into being as a direct result of being 'in Christ', that is, being united with Christ. Barth was determined to demonstrate the relation between justification and sanctification. For Barth the question of what comes before what in the ordo salutis is irrelevant. For Barth, all the benefits that come from redemption and regeneration are located in the union with Christ, and what human beings come to share in all of these when they are united to Christ. 
Barth is mentioned in this context not because he is the most important theologian in this area, but because he is one of the first to suggest a break with the anthropologically driven understanding of justification and sanctification that came to the fore under liberalism. There are two reasons why Barth is not the most important theologian in this area. Firstly, Barth was, for the most part, not overly interested in the subject of soteriology and actually subjected his soteriology, as he did with most of the other areas of his theology, to Christology. Secondly, Barth has been criticised for not making a radical enough break with the liberalism from which he was trying to escape. Yet, Barth is highlighted here because he did set the conversation of a new trajectory. By locating justification and sanctification within the context of union with Christ, Barth sought to return the focus on way in which God acts in saving human beings as opposed to a merely natural evolutionary process by which human nature is constantly on some sort of upward evolutionary moral curve.

Barth and neo-orthodox approach of which he was one of the early exponents had some profound outcomes. For example, using to some extent the approach advocated by Barth and others, Moltmann (1992) questions:

Is there any point today in looking around for general phenomena to 'convince the world of sin' and persuade men and women that in God's sight they are sinful? Or is it better to be specific and practical and to ask the victims of sin and its perpetrators? (p. 127)

Moltmann here rejects an ordo salutis that sees justification and sanctification as separated events, and sees an intrinsic link between the God who justifies and the God who brings justice to those who have been denied justice while, at the same time, calling for repentance from those who have been the perpetrators of injustice. Moltmann locates this threefold connection between justification, victims and oppressors in the cross where, he suggests (Douglas 2005):

[T]hat there is an important connection between God justifying us and God's work of creating justice among us, and that that connection occurs specifically within a doctrine of justification that is focused on the cross. So understood, justification and sanctification are inseparable doctrines. On the cross, Christ is justifying us in spite of our sin, but he also creating a sense of community and belonging - especially for victims of violence - that enables us to work for justice with him. (p. 115)

However, as Douglas points out, a focus upon Christ's sacrificial death as a critical consideration in both justification and sanctification can have some unintended consequences. There are those, like Catholic theologian Elizabeth A. Johnson, who responds from a feminist perspective that to view Jesus' death as required by God to pay the price for human sinfulness 'is virtually inseparable from an underlying image of God as an angry, bloodthirsty, violent and sadistic father, reflecting the very worst kind of male human behavior' (Johnson 1993:154). The other danger is that by emphasising the concept of Christ's self-sacrifice inherent in both justification sanctification, those who are in positions of vulnerability are encouraged to accept their inferior and often abusive situations by those who are more powerful politically, socially or economically than they are. Yet, we cannot remove the language or the concept of sacrifice from the doctrine of justification and sanctification without doing violence to the way in which the New Testament presents the concept of sacrifice in the life and death of Jesus. As Luke Timothy Johnson (1996) points out:

$[T]$ he four canonical Gospels are remarkably consistent on one essential aspect of the identity and mission of Jesus. Their fundamental focus is not on Jesus's wondrous deeds or his wise words. Their shared focus is on the character of his life and death. The all reveal the same pattern of radical obedience to God and selfless love toward other people. All four Gospels agree that discipleship follows the same messianic pattern. They do not emphasize the performance of certain deeds or the learning of certain doctrines. The insist on living according to the same pattern of life and death shown by Jesus. (pp. 157-158, [italics in the original])

To emphasise the self-sacrificial nature of sanctification can lead to two further attendant problems. On the one hand, oppressed persons are told to accept their oppression as part of their identification with Christ (Douglas 2005):

$[O]$ ppressed persons are told that by submitting to their oppression they are imitating Christ and will share in his reward. The tale simultaneously justifies the oppressor's actions ... and legitimizes the oppressive system. (p. 122)

The second is to see sanctification and self-sacrifice as an antidote to the sin of pride, and those who seek to assert themselves are regarded as guilty of the sin of pride. This is notably the case with women, who have traditionally been regarded as subservient to men and for people of colour who have been regarded as subservient to whites. When women and people of colour accept their roles defined in this way, their $\sin$ tends not to be the sin of pride, but the $\sin$ of accepting that by belonging to a certain class or group of people they are by nature subservient to another class or group. In such contexts, Plascow (1980) suggests:

[T] he language of self-sacrifice conflicts with personhood and becomes destructive when it suggests that the struggle to become a centred self, the achieve full independent selfhood is sinful. In this case, theology is not irrelevant to [the oppressed's] situation, but rather becomes another voice in the chorus of external expectation defining and confining the way in which [the oppressed] ought to live. (p. 87)

\section{The challenge of self-sacrifice to social ethics}

How then should we deal with this challenge to this doctrine of sanctification from the perspective of social ethics, especially from the view from below, from those who are oppressed and who struggle to establish their own personhood against a backdrop of patriarchy or racism? Douglas suggests that, if we take our submission to the Lordship of Christ seriously, there are three ways in which to address these criticisms. The first, he suggests, is to look 
at the situation of the early church's trajectory towards egalitarianism especially when viewed against the situation within other groups at the time. It is not that the early church always got this right, but that they understood that there was a direction in which they were supposed to be moving and that was the direction of greater equality. We should also adopt this trajectory, allowing God to lead us in the direction of overcoming division and inequality. The second he suggests is to regard Christ's sacrifice not only in terms of what it accomplished for the individual, but for what it accomplishes for the community and whether the sacrifices that occur are justifiable or unjustifiable. He contends that the distinction between justified and unjustified suffering has something to do with the capacity to choose. Justified suffering only occurs where the agent has capacity to choose whether or not to submit to the suffering because 'those who give of themselves must have a self to give' (Douglas 2005:125). Even the most terrible suffering can have redemptive consequences if the person who suffers understands that their suffering can lead to the benefit of another. We all know inspirational stories of people who suffered, often unjustly, but who embraced their suffering understanding the capacity of their suffering to bring good to others. If Jesus Christ is Lord, then he is not just the Lord of the believers, but the Lord of all, and all have a relationship with Christ as Lord and, consequently, with one another. When people come to understand the ambit and scope of the Lordship of Christ and what it means to live under that Lordship, they begin to learn what it means to love God with heart and soul and mind and strength, and to love their neighbour as themselves. Douglas' third caveat is, as he suggests, the most controversial. Those who exercise their agency and choose to suffer on behalf of another do so because they believe that it is possible for good to come from it (Douglas 2015):

\footnotetext{
Jesus's Lordship not only provides a model through which to defend the premise [that good can come out of suffering] but as a promise that as he works through us in the process of our sanctification, he will help us make the good of selfhood come out of the bad of self-sacrifice. For if Jesus's Lordship means nothing else, it means that by the power of the Holy Spirit, Jesus Christ continues to act in the world - including in our lives and through suffering - to bring about its promised fulfillment. (p. 125)
}

If we take seriously the possibility that both justification and sanctification are supernatural works of the Triune God which come to us through Word and sacrament, and which have as their purpose the development of the individual and the shaping of communities, then we can begin to understand that no amount of hardship or suffering can be regarded as meaningless. While we understand the gospel imperative to address and work to overcome human suffering, we must never exclude the possibility that justified suffering may well be one of the means by which God is working to overcome injustice and inequality. One has only to think of the hardships and sufferings experienced by those fighting against apartheid in South Africa, courageously born and sacrificially endured that ultimately brought down a vile and evil social system. Nothing is excluded from the ambit of the justifying and sanctifying work of God in individuals and communities. God has not left people to their own devices, God has not abandoned us, but it is God who is responding to human suffering by using that suffering in the grand project of working and shaping the world to conform more to the priorities of the rule and reign of God. Believers are not spectators, but are fellow workers with God in this grand project and it is often in their struggles and sacrifices that believers contribute most.

\section{Conclusion}

We began with something of a definition: a legitimate Christian social ethic is an expression of obedient love that flows from a relationship with God established through faith in God's love, or justification. Social ethics as a component of sanctification is the process of living out and giving external evidence of, and expression to, both individually and corporately, the reality of what happens internally when the persons are justified. Good works are integral in this process, whether as a result of participation in the sacraments or as a result of a supernatural work of the Spirit working through Word and sacrament or as a second gift of the Spirit. Such works, approved by God are also rewards. They are acts, by which the human being consciously obeys the will of God because the person loves God and desires to please God. They are acts which may have as their result human welfare, but their actual aim is to glorify and honour God. They are acts that come from union with Christ, and they must be consistent with the early church's trajectory towards egalitarianism. As people seek to live out their faithfulness to God in this way, they may well suffer, but even the most terrible suffering can have redemptive consequences if the person who suffers understands that their suffering can lead to the benefit of another. For if Jesus's Lordship means nothing else, it means that by the power of the Holy Spirit, Jesus Christ continues to act in the world - including in our lives and through suffering - to bring about its promised fulfilment.

\section{Acknowledgements Competing interests}

The author declares that he has no financial or personal relationships that may have inappropriately influenced him in writing this article.

\section{Author's contributions}

P.D.L. is the sole author of this article.

\section{Ethical considerations}

This article followed all ethical standards for research without direct contact with human or animal subjects. 


\section{Funding information}

This research received no specific grant from any funding agency in the public, commercial, or not-for-profit sectors

\section{Data availability}

Data sharing is not applicable to this article as no new data were created or analysed in this study.

\section{Disclaimer}

The views and opinions expressed in this article are those of the author and do not necessarily reflect the official policy or position of any affiliated agency of the author.

\section{References}

Berkhof, L., 1984, Systematic theology, Banner of Truth Trust, Edinburgh. Berkouwer, G., 1954, Faith and justification, Eerdmans, Grand Rapids, MI.

Billings, J.T., 2009, 'John Calvin's soteriology: On the mutifaceted sum of the Gospel', International Journal of Systematic Theology 11(4), 428-447. https://doi. org/10.1111/j.1468-2400.2009.00470.x

Bromiley, G., 1978, Historical theology: An introduction, Eerdmans, Grand Rapids, MI.
Douglas, M., 2005, Confessing Christ in the twenty first century, Rowan and Litlefield Publishers Inc., Langham, MD.

Garcia, M.A., 2004, Life in Christ: The function of union with Christ in the Unio-Duplex Gratia structure of Calvin's soteriology: With special reference to the relationship of justification and sanctification in sixteenth-century context, viewed 25 July 2021, from https://www.researchgate.net/publication/36196968_Life_in_Christ_ the_function_of_union_with_Christ_in_the_Unio-Duplex_Gratia_structure_of_the_function_of_union_with_Christ_in_the_Unio-Duplex_Gratia_structure_of justification_and_sanctification_in_sixteenth/cita.

Garcia, M.A., 2009, 'Imputation as attribution: Union with Christ, reification and justification as declarative word', International Journal of Systematic Theology 11(4), 415-427. https://doi.org/10.1111/j.1468-2400.2009.00472.x

Hutcinson, J.A., 1956, Faith, reason and existance: An introduction to contemporary philosophy of religion, Oxford University Press, New York, NY.

Johnson, E.A., 1993, She who is: The mystery of God in feminist discourse, Crossroads, New York, NY.

Johnson, L.T., 1996, The real Jesus, Harper, San Francisco, CA.

Mcgrath, A.E., 2000, A history of the Christian doctrine of justification, Cambridge University Press, Cambridge.

Moltmann, J., 1992, The spirit of life, Fortress Press, Minneapolis, MN.

Plascow, J., 1980, Sex, sin and grace: Women's experience and the theologies of Reihold Niebuhr and Paul Tillich, University Press of America, Lanham.

The Joint Declaration of the Doctrine of Justification, 2019, Geneva: Lutheran World Federation, viewed 15 May 2021, from https://www.lutheranworld.org/sites/ default/files/Joint\%20Declaration\%20on\%20the\%20Doctrine\%20of\%.

Venema, C.P., 2007, 'Calvin's understanding of the "Twofold Grace of God" and contemporary ecumenical discussion of the Gospel', Mid America Journal of Theology 18, 67-105.

Wallace, R.S., 1959, Calvin's Doctrine of the Christian Life, Oliver \& Boyd, Edinburgh. 